УДК 667.27

DOI 10.30679/2219-5335-2021-1-67-385-394

ИСПОЛЬЗОВАНИЕ

КОНЦЕНТРИРОВАННОГО

ЭКСТРАКТА ВИНОГРАДНОЙ

ВЫЖИМКИ В КАЧЕСТВЕ

НАТУРАЛЬНОГО КРАСИТЕЛЯ

\author{
Смирнов Анатолий Сергеевич \\ инженер-технолог \\ пищевого производства \\ e-mail: as.expert@inbox.ru
}

Общество с ограниченной

ответственностью «Вкуснолето», Санкт-Петербург, Красное Село, Россия

Использование вторичных ресурсов аграрного производства является одной из главных задач в защите окружающей среды. В работе рассмотрены принципы получения концентрированного экстракта виноградной выжимки из красного сорта винограда Гранатовый и его применения в производстве мармелада.

Для проведения концентрирования экстракта использован роторный испаритель, Получен коэффициент концентрирования равный 10. Установлено, что проведение концентрирования экстракта, полученного из сброженной виноградной выжимки, обеспечивает ее стабильность и улучшает технологические показатели. В исходном экстракте содержание антоцианов определялось фотоколориметрически, содержание органических кислот, катионов калия, натрия, магния, кальция - методом капиллярного электрофореза. Полученный экстракт содержал токсичные металлы в пределах допустимого уровня, обладал интенсивной красной окраской в слабокислой среде и был использован в качестве корректирующего натурального красителя в технологии мармелада. Экспериментальные образцы мармелада были подвергнуты дегустации.

В процедуре сенсорной оценки участвовали
UDC 667.27

DOI 10.30679/2219-5335-2021-1-67-385-394

\section{USING \\ OF CONCENTRATED GRAPE POMACE EXTRACT AS A NATURAL COLORING SUBSTANCE}

\author{
Smirnov Anatoliy Sergeyevich \\ Food Production Process \\ Engineer \\ e-mail: as.expert@inbox.ru

\section{Limited Liability Company \\ "Vkusnoleto», \\ St. Petersburg, Krasnoe Selo, Russia}

The use of secondary resources of the agrarian industry is one of the main tasks in environment protecting. The paper considers the principles of obtaining a concentrated extract of grape pomace from the red grape Granatovy variety and its use in the production of marmalade. For concentrating the extract, a rotary evaporator was used, the concentration factor was equal to 10 . It was found that extract concentrating from fermented grape pomace ensures its stability and improves technological indicators. In the original extract, the content of anthocyanins is determined by photocolorimetric metod, the content of organic acids, potassium, sodium, magnesium, calcium cations - by capillary electrophoresis. The extract obtained contained the toxic metals within the permissible level and had an intense red color in a weakly acidic environment, it was used as a correcting natural dye in the marmalade technology. Experimental marmalade samples were tasted. The sensory assessment procedure involved 10 specialists, including 6 women and 4 men, aged 29-45 years old (7 people), 
10 специалистов -6 женщин и 4 мужчин, в возрасте 29-45 лет (7 человек) и 46 -65 лет (3 человека). Все участники являются экспертами в области кондитерских изделий, работают в кондитерской промышленности и обладают профессиональным опытом в области сенсорного анализа. Результаты сенсорной оценки выражали по 5-балльной шкале оценок. Лучшую дегустационную характеристику получил образец мармелада с добавкой концентрированного виноградного экстракта (0,3 \%), общий балл был равен 17,5. Контрольный образец на искусственном красителе был оценен на 14,9 балла. В рамках данной статьи разобран состав экстракта виноградных выжимок, приведена технология получения экстракта и его дальнейшего использования на кондитерском производстве.

Ключевые слова: ЭКСТРАКТ, ВЫЖИМКА, ВИНОГРАД, КОНЦЕНТРАТ, МАРМЕЛАД, НАТУРАЛЬНЫЙ КРАСИТЕЛЬ, КИСЛОТА and 46-65 years old (3 people). All participants are confectionery experts, work in the confectionery industry and have professional experience in sensory analysis. Sensory assessment results were expressed on a 5-point rating scale. The best tasting characteristic was obtained for a sample of marmalade with the addition of a concentrated grape extract of $0.3 \%$ by weight, the total score was 17.5.

The control sample on an artificial color substance was rated at 14.9 points. Within the framework of this article, the composition of the extract of grape pomace is analyzed, the technology for obtaining the extract and its further use in the confectionery industry is presented.

Key words: EXTRACT, POMACE, GRAPES, CONCENTRATE, MARMALADE, NATURAL DYE, ACID

Введение. В соответствии с распоряжением правительства РФ от 17 апреля 2012 г. № 559-р «Стратегия развития пищевой и перерабатывающей промышленности Российской Федерации на период до 2020 года» необходимо повысить глубину переработки сырья, вовлечь в хозяйственный оборот вторичные ресурсы, что позволит увеличить выход готовой продукции из перерабатываемого сырья [1]. Особое внимание в современных реалиях экономики страны уделено усилению импортозамещаемым отраслям промышленности, в частности виноградарству и виноделию.

Президентом РФ Путиным В.В. был подписан Федеральный закон от 27.12.2019 № 468-Ф3 "О виноградарстве и виноделии в Российской Федерации" [2]. Закон позволяет поддерживать производителей винограда и вина, определяет критерии качества продукции и должен улучшить ситуацию в отрасли, где производство готового вина не растет с 2017 года. Тем не менее общий объем производства столового вина составил в 2019 году. 32 млн. 
дал, шампанских и игристых вин 132 млн. дал и коньяков 9,2 млн. дал [3], для выработки этой продукции потребовалось собрать и переработать более 678 тысяч тонн винограда [4].

Эффективный выход виноматериала из винограда составляет не более 80 \%, таким образом, на отходы приходится не менее 134 тысяч тонн. Отходы виноделия являются ценным вторичным сырьем и в данный момент ограниченно утилизируются. Часто их сваливают в ямы, где они перегнивают, тем самым ухудшая экологическую обстановку окрестностей. Частично отходы используют как удобрение или как исходный материал для получения спирта и продуктов из него [5]. Большая часть отходов - это виноградная выжимка, которая остается в прессе после отжима сока из свежего или уже перебродившего винограда, в основном - гребни, кожица, семена и остатки жидкости (сусло или вино) [6,7].

В настоящее время растет интерес к выжимкам виноградных отходов как к источнику биологически ценных компонентов, так как из них можно получать новые виды высококачественной продукции, в том числе биологически активные добавки [8-10]. В зависимости от направления переработки сырья получают сладкие или сброженные выжимки. Сладкие выжимки также называют белыми, они содержат только сахар и чаще всего получаются после прессования белого винограда. Сброженные или красные выжимки, напротив, содержат значительные количества спирта и практически не содержат углеводы.

Химический состав виноградных выжимок аналогичен составу виноградной ягоды. Кроме сахара или спирта выжимки содержат и ряд других веществ, среди которых азотистые, пектиновые, фенольные, дубильные и красящие вещества, а также клетчатка и жиры. Органические кислоты в виноградных выжимках представлены щавелевой, яблочной, глюконовой, лимонной, винной и их солями. Также выжимки содержат большие количества фенольных соединений, которые проявляют хорошо выраженные антиоксидантные свойства [11]. Кожица винограда содержит полифенолы, лигнин, 
красящие, ароматические и минеральные вещества, витамины и аминокислоты $[12,13]$. Виноградная кожица содержит и другие компоненты, например полисахаридолигниновый комплекс из целлюлозы, гемицеллюлоз и полимера фенилпропаналигнина, который является пищевым волокном [14].

Особый интерес в виноградных выжимках представляет винная кислота, которую выделяют из самих выжимок и сусловых осадков. Красные выжимки содержат в среднем 0,9 \% винной кислоты, в то время как белые 0,5 \%. Не менее значимым компонентом является пищевой краситель (энокраситель) - энотаннин, который вырабатывают из выжимок интенсивно окрашенных красных сортов винограда. К сожалению, пока что из вторичного сырья винодельческих предприятий получают виннокислую известь и спирт, несмотря на то, что эти отходы содержат и ряд других крайне ценных продуктов [15].

В кожице красных сортов винограда содержатся вещества, которые обладают повышенной антиоксидантной активностью - антоцианы (до 650 мг/дм³). Благодаря своим свойствам антоцианы в некоторой степени предотвращают старение организма человека и разрушение клеток кровеносных сосудов, чем оказывают положительное влияние на здоровье человека в целом [16].

Виноградные выжимки содержат в больших количествах дисахариды, пектиновые вещества, клетчатку. Попадание в организм человека недостаточного количества пищевых волокон может привести к осложнениям в виде таких заболеваний, как сахарный диабет, ишемическая болезнь сердца, атония кишечника и атеросклероз. Помимо этого пищевые волокна могут снижать усваиваемость пищи и увеличивать расход энергии при обмене веществ, за счет чего наблюдается снижение веса у людей, страдающих ожирением. Клетчатка так же, как и инсулин, понижает содержание глюкозы в крови $[17,18]$.

Полисахариды, которые образуются за счет остатков галактуроновой кислоты, - пектины - способствуют выведению тяжелых металлов, вредных 
Плодоводство и виноградарство Юга России № 67(1), 2021 г.

продуктов обмена и радионуклидов из организма человека [19]. Обсудив состав виноградных выжимок, подходим к вопросу получения концентрата и сохранения в нем максимального количества полезных веществ.

Цель работы - изучение и получение экстракта виноградной выжимки для оптимизации его дозировки в рецептуру мармелада.

Объекты и методы исследований. Исследовали сброженную выжимку винограда Гранатовый урожая 2019г;; экстракт, полученный из нее с помощью 1 \%-ной соляной кислоты; мармелад, выработанный с применением концентрированного экстракта виноградной выжимки. Влажность выжимки определяли гравиметрическим способом, содержание антоцианов фотоколориметрически, содержание органических кислот, катионов калия, натрия, магния, кальция - методом капиллярного электрофореза [20]. Контроль токсичных металлов осуществляли методом атомной абсорбции («Квант-АФА», ООО КОРТЭК). Исходная влажность сброженной выжимки сорта Гранатовый составляла $23-26 \%$.

Обсужнение результатов. Доктором химических наук Ю.Ф. Якубой в Северо-Кавказском федеральном научном центре садоводства, виноградарства, виноделия (далее ФГБНУ СКФНЦСВВ) были проведены эксперименты по экстракции биологически активных веществ и антоцианов из сладкой и сброженной выжимки водой и растворами соляной кислоты $[20,21]$. Было установлено, что главным критерием, который определяет качество экстрактов из выжимки красных сортов винограда, является содержание уксусной кислоты. Показано, что выход веществ различных классов после экстракции, а особенно катионов щелочных и щелочно-земельных металлов, а также винной кислоты, существенно возрастает при экстракции в кислой среде. Также результаты исследований подтверждают возможность использования виноградной выжимки красных сортов винограда в качестве исходного сырья для получения экстракта, обогащённого БАВ и антоцианами [22]. 
В рамках исследования производства концентрированного виноградного экстракта определили, что полнота экстракции биологически ценных компонентов выжимки достигается с помощью 1 \%-ной соляной кислоты, pH менее 1,0; содержание сухих водорастворимых веществ составляет около $4 \%$. Далее концентрирование экстракта проводили на роторном вакуумном испарителе до 40 \% сухих веществ, в результате чего достигали 10ти кратного сокращения объема. Образцы экстракта, концентрированного до 40 \% сухих веществ, использовали для получения кондитерской продукции на мощностях компании ООО «Вкуснолето».

Были проведены исследования при добавлении экстракта виноградной выжимки в качестве красителя с высоким содержанием полезных веществ - натурального красителя, органических кислот, катионов калия, магния - в мармелад, зефир и выпечные изделия. При изготовлении сахаристых кондитерских изделий - мармелада на пектине было выпущено 3 варианта изделий с добавлением $0,1 \%, 0,3 \%$ и 0,5 \% экстракта из сорта винограда Гранатовый, селекции СКФНЦСВВ. Содержание в концентрате антоцианов составило 6500 мг/кг, использование 0,3 \% концентрата позволило получить продукт с содержанием антоцианов 2 мг/100 г.

При выпуске мармелада приготавливался сахаро-паточный сироп с добавлением пектина и варкой смеси до 78 \% сухих веществ, добавлением лимонной кислоты и концентрированного экстракта до требуемых показаний кислотности смеси (pH 3,3). Далее смесь разливали по силиконовым формочкам, и она застывала в течение 60 минут. Дегустацию готового мармелада проводили, сравнивая с мармеладом на искусственном фиолетовом красителе и ароматизаторе «Виноград красный» $(0,5 \%$ масс.).

Все экспериментальные исследования, связанные с сенсорным анализом, проведены в помещении для дегустаций на производственной площадке ООО «Вкуснолето» г. Санкт-Петербург, г. Красное Село, РФ. Общий описательный анализ был проведен на 4-х образцах мармелада, включающих 1 образец на искусственных красителях и ароматизаторах («Виноград 
красный») и по 1 образцу с концентрацией $0,1 \%, 0,3 \%$ и 0,5 \% экстракта выжимки виноградного сусла в составе мармелада.

В процедуре сенсорной оценки участвовали 10 специалистов: 6 женщин и 4 мужчин, в возрасте 29-45 лет (7 человек) и 46-65 лет (3 человека). Все участники являются экспертами в области кондитерских изделий, работают в кондитерской промышленности и обладают профессиональным опытом в области сенсорного анализа. Результаты сенсорной оценки выражали по 5-балльной шкале. Мармелад в виде сфер без покрытия по 12 г подавали в закрытых чашечках Петри по 1 изделию в каждой чашечке, промаркированной номерами. Изделия подавали с температурой 20-22 ${ }^{\circ} \mathrm{C}$, испытания проводили в помещении для дегустации с контролируемым температурным режимом и ламповым освещением. Образцы были поданы при $18-22{ }^{\circ} \mathrm{C}$ и относительной влажности 65 \% за столами с белыми салфетками и питьевой водой. Дегустаторам не разрешалось общаться во время процедуры. Вычисляли среднее арифметическое значений оценок с точностью до первого знака после запятой. В результате дегустации продукции была получена таблица результатов дегустации.

Результаты дегустации опытных образцов мармелада

\begin{tabular}{|c|c|c|c|c|}
\hline $\begin{array}{c}\text { Состав добавки } \\
\text { и концентрация } \\
\text { экстракта в продукте }\end{array}$ & Цвет & Вкус & Запах & Кислота \\
\hline $\begin{array}{l}\text { Искусственный } \\
\text { краситель } \\
\text { и ароматизатор }(0,5 \%) \\
\text { - контроль }\end{array}$ & $\begin{array}{c}\text { Фиолетовый } \\
4,4\end{array}$ & $\begin{array}{c}\text { Сильный } \\
\text { химический вкус } \\
4,0\end{array}$ & $\begin{array}{c}\text { Сильный } \\
\text { запах } \\
\text { винограда } 3,5\end{array}$ & $\begin{array}{c}\text { Кислый } \\
3,0\end{array}$ \\
\hline 0,1% экстракта & $\begin{array}{c}\text { Розовый } \\
3,3\end{array}$ & $\begin{array}{c}\text { Почти } \\
\text { не ощущается } \\
2,3\end{array}$ & $\begin{array}{c}\text { Почти } \\
\text { не слышен } \\
2,2\end{array}$ & \begin{tabular}{|c|} 
Почти \\
не ощущается \\
2,2
\end{tabular} \\
\hline 0,3 \% экстракта & $\begin{array}{c}\text { Фиолетовый } \\
4,5\end{array}$ & $\begin{array}{c}\text { Вкус красного } \\
\text { винограда } 4,2\end{array}$ & \begin{tabular}{|c|} 
Запах \\
виноградного \\
сока 4,4
\end{tabular} & $\begin{array}{c}\text { Немного } \\
\text { кислый 4,4 }\end{array}$ \\
\hline 0,5 \% экстракта & $\begin{array}{c}\text { Темно- } \\
\text { фиолетовый } \\
4,0\end{array}$ & $\begin{array}{c}\text { Терпкий вкус вина } \\
3,5\end{array}$ & $\begin{array}{c}\text { Запах вина } \\
3,3\end{array}$ & $\begin{array}{c}\text { Кислый } \\
3,5\end{array}$ \\
\hline
\end{tabular}


Плодоводство и виноградарство Юга России № 67(1), 2021 г.

Консистенция, текстура и плотность мармеладной массы показали одинаковые значения независимо от вида добавки и ее вкуса, поэтому в таблице не приведены. Лучшая дегустационная характеристика дана образцу с добавкой концентрированного виноградного экстракта 0,3\%, его итоговый балл равен 17,5, в то время как контрольный образец на искусственном красителе получил 14,9 балла. По решению компании концентрат экстракта из виноградных выжимок будет использоваться далее при производстве мармелада с виноградным вкусом.

Заключение. Использование экстракта выжимки винограда как источника ценных натуральных веществ поможет решить не только вопрос утилизации самих выжимок, но и обеспечить рацион человека многими полезными веществами растительного происхождения. Концентрирование экстракта до содержания сухих веществ 40 \% массовых обеспечило его стабильность и улучшило показатели технологичности. Дегустационная комиссия позволила установить преимущество применения концентрированного виноградного экстракта в мармеладе с концентрацией 0,3 \% в сравнении с контрольным образцом на искусственном красителе с концентрацией 0,5 \%.

\section{Литература}

1. Распоряжение правительства РФ от 17 апреля 2012 г. N 559-р Стратегия развития пищевой и перерабатывающей промышленности Российской Федерации на период до 2020 года [Электронный ресурс]. Режим доступа: http://consultant.ru (дата посещения: 13.10.2020)

2. http://docs.cntd.ru/document/564069019

3. https://ac.gov.ru/news/page/eksperty-otmetili-rost-proizvodstva-alkogola-v-rossii-v2019-godu-26577

4. https://ab-centre.ru/news/rossiyskiy-rynok-vinograda---klyuchevye-tendencii-2

5. Алкогольный напиток из виноградных выжимок [Электронный ресурс] Коллекция виноградных дистиллятов «Чача». Режим доступа: http://www.fanagoria.ru (дата обращения: 21.10.2020).

6. Dallas, C. Effect of $\mathrm{SO}_{2}$ on the extraction of individual anthocyanins and colored matter of three Portuguese grape varieties during winemaking / C. Dallas, O. Laureano // Vitis. - 1994. - V.33. - P.41-47.

7. Sahpazidou, D. Anticarcinogenic activity of polyphenolic extracts from grape stems against breast, colon, renal and thyroid cancer cells / D. Sahpazidou, G.D. Geromichalos, D. Stagos, A. Apostolou, S.A. Haroutounian, A.M. Tsatsakis, G.N. Tzanakakis, A.W. Hayes, D. Kouretas // Toxicol. Lett. - 2014. - V.230. - P. 218-224. 
8. Исригова Т.А., Мусаева Н.М., Салманов М.М. Биологически активные добавки из семян, кожицы и гребней винограда // Проблемы развития АПК региона. 2012. Т 10. C. 113-119.

9. Xia, E. Biological activities of polyphenols from grapes / E. Xia, G. Deng, Y.-J. Guo, H.-B. Li // Int. J. Mol. Sci. - 2010. - V. 11. - P. 622-646.

10. Haroutounian, S. Polyphenolic composition of grape stem extracts affects antioxidant activity in endothelial and muscle cells / S. Haroutounian, D.A. Spandidos, A.M. Tsatsakis, D. Kouretas // Mol. Med. Rep. - 2015.- V.12. - P. 5846-5856.

11. Юрченко А.Е. Вторичные материальные ресурсы пищевой промышленности (образование и использование). Справочник. М.: Экономика, 1984. 327 с.

12. Gouvinhas, I. Monitoring the antioxidant and antimicrobial power of grape (Vitis vinifera L.) stems phenolics over long-term storage / I. Gouvinhas, R. Santos, M. Queiroz, C. Leal, M. J. Saavedra, R. Dominguez-Perles, M. Rodrigues, A.I.R.N.A. Barros // Industrial Crops and Products. - 2018. - V.126. - P. 83-91.

13. Vazquez-Armenta, F.J. Phenolic extracts from grape stems inhibit Listeria monocytogenes motility and adhesion to food contact surfaces / F.J. Vazquez-Armenta, A.T. BernalMercado, J. Lizardi-Mendoza, B.A. Silva-Espinoza, M.R. Cruz-Valenzuela, G.A. Gonzalez-Aguilar, F. Nazzaro, F. Fratianni, J.F. Ayala- Zavala // J. Adhes. Sci. Technol. - 2017. -V. 4243. - P. 1-19.

14. Пищевые волокна / М.С. Дудкин [и др.]. К.: Урожай, 1988. 152 с.

15. Руководство по технологии получения и переработки растительных масел и жиров. Том 1, книга 2. Л., 1974. 590 с.

16. Costantini, A. Clinical and capillaroscopic evaluation of chronic uncomplicated venous insufficiency with procyanidins extracted from Vitis vinifera / A. Costantini., T. De Bemardi, A. Gotti // Minerva Cardioangiol. -1999. - V. 47 - № 1-2. - 39-46 p

17. Кричман Е.С. Пищевые волокна и их роль в создании продуктов здорового питания // Пищевая промышленность. 2007. № 8. С. 62-63.

18. Беркетова Л. В. Биологически активные добавки источники пищевых волокон // Пищевая промышленность. 2003. № 6. С. 80-82.

19. Донченко Л.В. Технология пектина и пектинопродуктов. М.: ДеЛи, 2000. $255 \mathrm{c}$.

20. Якуба Ю.Ф. Анализ состояния нормативного обеспечения качества винодельческой продукции // Заводская лаборатория. Диагностика материалов. 2009. Т.75. № 8. C. 68-71.

21. Якуба Ю.Ф., Марковский М.Г. Электрофоретическое определение хлорида, сульфата, нитрата, нитрита в винах // Аналитика и контроль. 2011. Т.15. № 3. С. 305-308.

22. Изучение условий экстракции виноградной выжимки сортов Мерло и Каберне Совиньон [Электронный ресурс] / А.И. Ферзаули [и др.] // Плодоводство и виноградарство Юга России. 2019. № 55(1). С. 165-176. URL: http://journalkubansad.ru/pdf/19/01/15.pdf. DOI: 10.30679/2219-5335-2019-1-55-165-176 (дата обращения: 20.01.2021).

\section{References}

1. Rasporyazhenie pravitel'stva RF ot 17 aprelya 2012 g. N 559-r Strategiya razvitiya pishchevoj i pererabatyvayushchej promyshlennosti Rossijskoj Federacii na period do 2020 goda [Elektronnyj resurs]. Rezhim dostupa: http://consultant.ru (data poseshcheniya: 13.10.2020)

2. http://docs.cntd.ru/document/564069019

3. https://ac.gov.ru/news/page/eksperty-otmetili-rost-proizvodstva-alkogola-v-rossii-v2019-godu-26577 
4. https://ab-centre.ru/news/rossiyskiy-rynok-vinograda---klyuchevye-tendencii-2

5. Alkogol'nyj napitok iz vinogradnyh vyzhimok [Elektronnyj resurs] Kollekciya vinogradnyh distillyatov «Chacha». Rezhim dostupa: http://www.fanagoria.ru (data obrashcheniya: 21.10.2020).

6. Dallas, C. Effect of SO2 on the extraction of individual anthocya-nins and colored matter of three Portuguese grape varieties during winemak-ing / C. Dallas, O. Laureano // Vitis. - 1994. - V.33. - P.41-47.

7. Sahpazidou, D. Anticarcinogenic activity of polyphenolic extracts from grape stems against breast, colon, renal and thyroid cancer cells / D. Sahpazidou, G.D. Geromichalos, D. Stagos, A. Apostolou, S.A. Haroutounian, A.M. Tsatsakis, G.N. Tzanakakis, A.W. Hayes, D. Kouretas // Toxicol. Lett. - 2014. - V.230. - P. 218-224.

8. Isrigova T.A., Musaeva N.M., Salmanov M.M. Biologicheski aktivnye dobavki iz semyan, kozhicy i grebnej vinograda // Problemy razvitiya APK regiona. 2012. T 10. S. 113-119.

9. Xia, E. Biological activities of polyphenols from grapes / E. Xia, G. Deng, Y.-J. Guo, H.-B. Li // Int. J. Mol. Sci. - 2010. - V. 11. - P. 622-646.

10. Haroutounian, S. Polyphenolic composition of grape stem extracts affects antioxidant activity in endothelial and muscle cells / S. Haroutounian, D.A. Spandidos, A.M. Tsatsakis, D. Kouretas // Mol. Med. Rep. - 2015.- V.12. - P. 5846-5856.

11. Yurchenko A.E. Vtorichnye material'nye resursy pishchevoj promyshlennosti (obrazovanie i ispol'zovanie). Spravochnik. M.: Ekonomika, 1984. 327 s.

12. Gouvinhas, I. Monitoring the antioxidant and antimicrobial power of grape (Vitis vinifera L.) stems phenolics over long-term storage / I. Gouvinhas, R. Santos, M. Queiroz, C. Leal, M. J. Saavedra, R. Dominguez-Perles, M. Rodrigues, A.I.R.N.A. Barros // Industrial Crops and Products. - 2018 .- V.126. - P. 83-91.

13. Vazquez-Armenta, F.J. Phenolic extracts from grape stems inhibit Listeria monocytogenes motility and adhesion to food contact surfaces / F.J. Vazquez-Armenta, A.T. BernalMercado, J. Lizardi-Mendoza, B.A. Silva-Espinoza, M.R. Cruz-Valenzuela, G.A. GonzalezAguilar, F. Nazzaro, F. Fratianni, J.F. Ayala- Zavala // J. Adhes. Sci. Technol. - 2017. V. 4243. - P. 1-19.

14. Pishchevye volokna / M.S. Dudkin [i dr.]. K.: Urozhaj, 1988. 152 s.

15. Rukovodstvo po tekhnologii polucheniya i pererabotki rastitel'nyh masel i zhirov. Tom 1, kniga 2. L., 1974. $590 \mathrm{~s}$.

16. Costantini, A. Clinical and capillaroscopic evaluation of chronic uncomplicated venous insufficiency with procyanidins extracted from Vitis vinifera / A. Costantini., T. De Bemardi, A. Gotti // Minerva Cardioangiol. -1999. - V. 47 - № 1-2. - 39-46 p

17. Krichman E.S. Pishchevye volokna i ih rol' v sozdanii produktov zdorovogo pitaniya // Pishchevaya promyshlennost'. 2007. № 8. S. 62-63.

18. Berketova L. V. Biologicheski aktivnye dobavki istochniki pishchevyh volokon // Pishchevaya promyshlennost'. 2003. № 6. S. 80-82.

19. Donchenko L.V. Tekhnologiya pektina i pektinoproduktov. M.: DeLi, 2000. 255 s.

20. Yakuba Yu.F. Analiz sostoyaniya normativnogo obespecheniya kachestva vinodel'cheskoj produkcii // Zavodskaya laboratoriya. Diagnostika materialov. 2009. T.75. № 8. S.68-71.

21. Yakuba Yu.F., Markovskij M.G. Elektroforeticheskoe opredelenie hlorida, sul'fata, nitrata, nitrita v vinah // Analitika i kontrol'. 2011. T.15. № 3. S. 305-308.

22. Izuchenie uslovij ekstrakcii vinogradnoj vyzhimki sortov Merlo i Kaberne Sovin'on [Elektronnyj resurs] / A.I. Ferzauli [i dr.] // Plodovodstvo i vinogradarstvo Yuga Rossii. 2019. № 55(1). S. 165-176. URL: http://journalkubansad.ru/pdf/19/01/15.pdf. DOI: 10.30679/22195335-2019-1-55-165-176 (data obrashcheniya: 20.01.2021). 